Volume 13

Issue 2 Rethinking Genocide, Mass Atrocities,

and Political Violence in Africa: New Directions,

Article 12

New Inquiries, and Global Perspectives

6-2019

\title{
Peace and Compromise, Idealism and Constraint: The Case of the Arusha Peace Accords in Rwanda and Burundi
}

Jonathan R. Beloff

SOAS University of London

Samantha Lakin

Clark University

Follow this and additional works at: https://digitalcommons.usf.edu/gsp

\section{Recommended Citation}

Beloff, Jonathan R. and Lakin, Samantha (2019) "Peace and Compromise, Idealism and Constraint: The Case of the Arusha Peace Accords in Rwanda and Burundi," Genocide Studies and Prevention: An International Journal: Vol. 13: Iss. 2: 129-147.

DOI:

https://doi.org/10.5038/1911-9933.13.2.1696

Available at: https://digitalcommons.usf.edu/gsp/vol13/iss2/12

This Articles is brought to you for free and open access by the Open Access Journals at Digital Commons @ University of South Florida. It has been accepted for inclusion in Genocide Studies and Prevention: An International Journal by an authorized editor of Digital Commons @ University of South Florida. For more information, please contact digitalcommons@usf.edu. 


\title{
Peace and Compromise, Idealism and Constraint: The Case of the Arusha Peace Accords in Rwanda and Burundi
}

\author{
Jonathan Beloff \\ SOAS University of London \\ London, England \\ Samantha Lakin \\ Clark University \\ Worcester, Massachusetts, USA
}

Peace and stability have been core challenges in the Great Lakes Region of Africa since the years of independence from European nations. State building processes have been ridden by ongoing violence, characterized by two-sided or multi-party violence perpetrated by militias, national militaries, rogue groups, and even local civilians. The international system has prioritized peace accords and negotiation processes when parties in conflict decide to move past the violence, either required by external actors, or based on the unsustainability of the situation on the ground. When warring parties and international actors sign peace accords to end conflict in an attempt to begin political dialogue, they often reinforce the international legal assumption that these negotiations will bring about positive change, including peace and stability. The cases of Rwanda and Burundi are complicated, with social, historical, political, ideological, and economic factors leading to violence on the ground. The Arusha Accords of 1993 in Rwanda and of 2000 in Burundi were followed only by short-term stability, with an eventual return to conflict. This study examines the effects of the Arusha Peace Accords signed prior to the 1994 genocide in Rwanda, and the Arusha Accords of 2000, which ended 12 years of civil war in Burundi. As shown in this paper and through our research, peace negotiations and peace processes take place in an unideal situation, yet in order for future peace to be achieved they must be attempted. The failure of Arusha in Rwanda and in Burundi show some of the complexities and challenges faced in these two case studies, and analyze why there was a return to violence in each case.

\section{Methodology}

The research on Rwanda's history and lasting effects of the 1993 Arusha Accords stems from existing scholarly literature as well as qualitative interview and observational data gathered during research periods in Rwanda. Beginning in 2008 until 2016, semi-structured interviews have been conducted with named and anonymous elite Rwandan officials involved in the negotiation of the accords as well as rebuilding the country after the 1994 genocide, also referred to as the 1994 Genocide Against the Tutsis. While interviewing Rwandan Government officials is controversial, ${ }^{1}$ their role in the negotiation or reconstruction of Rwanda after the Arusha Accords provides unique insights and illustrates their perceptions of Arusha's effects on Rwanda. Some informants were willing to have their names attached to their statements while others, mostly mid-level officials, requested their statements be recorded, but not identified. Many explained their desire for their names to be withheld stemmed from fear of possible loss of employment from the government as some views might be considered controversial. Some Rwandan civilians working for genocide remembrance institutions also requested their names be withheld. The information was analyzed through triangulation methods to uncover major themes and Rwandan perceptions of the short and long-term effects of the accord. For the comparative research on Burundi and the 2000 Arusha Accords, the authors have conducted a robust review of secondary literature, and have also reviewed primary source newspaper articles, United Nations and African Union reports, and independent commission and governmental reports, since April 2015. In addition, interviews were conducted in June 2015, December 2016, and June 2016 with Burundian refugee leaders, including opposition members living in Rwanda, Europe, and the United States. As it was impossible to enter Burundi to conduct the research due to the lack of openness, security risks, and suspicion of foreign

\footnotetext{
${ }^{1}$ Phil Clark, "Must Academics Researching Authoritarian Regimes Self-Censor," Times Higher Education, November 28, 2013; Erin Jessee, "Conducting Field Work," Canadian Journal of Development Studies/Revue Canadienne D'études Du Développement 33, no. 2 (2012), 266-274.
} 
researchers, we were unable to interview leaders of the current Nkurunziza regime. Therefore, the analysis of the governmental perspective is based on a review of secondary and primary source documents and reports collected by the researchers.

\section{Case Situation within the Literature on Peace Negotiations and Compromise}

It is important to consider how existing literature about peace negotiations and compromise elucidate the challenges inherent to and created during peace negotiations, specifically in complex and violent humanitarian emergencies with less than ideal realities on the ground. "On Complicity and Compromise" by Lepora and Goodin provides a significant example of a humanitarian doctor who is asked in the midst of conflict in a war-torn country if a militia soldier should use condoms when he rapes a woman. The humanitarian doctor told the young soldier, "Yes." However, the ethicist (Lepora) responds by questioning whether the doctor gave the right answer, and if she was somehow complicit in "any rape the soldier would perpetrate in the future?" 2 This dilemma shows how reality in situations like the Arusha negotiations in pre-genocide Rwanda and those peace negotiations among the ongoing atrocities in Burundi complicate the ability to make moral choices in situations that are far less than ideal. Of the book, Hugo Slim says, "in such settings, when we cannot stop wider wrongs, some level of complicity may be unavoidable, even desirable, so as to secure the limited moral goods that we can achieve. Still, such decisions always leave us with an aching sense of moral distress." ${ }^{3}$

The book addresses the relevant theme of complicity as political rhetoric, yet this article shows that the political sphere where the Arusha negotiations took place had real impacts on the lives of Rwandans, Burundians, and refugees in the region. According to "A post-liberal peace" edited by Oliver P. Richmond, ${ }^{4}$

Liberal peacebuilding has caused a range of unintended consequences. These emerge from the liberal peace's internal contradictions, from its claim to offer a universal normative and epistemological basis for peace, and to offer a technology and process which can be applied to achieve it. When viewed from a range of contextual and local perspectives, these topdown and distant processes often appear to represent power rather than humanitarianism or emancipation.

The point is that oftentimes these top-down processes lack a real connection with the lived experiences and realities of people on the ground. This was especially the case in Rwanda in 1993, when the Arusha negotiations were taking place, but neither Habyiramana's regime nor the Rwandan Patriotic Front (RPF) truly trusted the process. Tutsis were still being killed on the ground and fear was rampant. In addition, while the RPF integrated into the government, they also continued to prepare militarily, in case Arusha fell through. This shows alternatives created by local groups, as Richmond and his colleagues state, occurring parallel to the official, top-down processes. Lastly, however, top-down processes in the Rwandan and Burundian cases are not black and white, as the liberation movements consisted of leaders who were refugees, trained in local situations, operating on the ground and not in traditional political spaces. The divulgence and mélange of the formal and informal, the elite and local become mixed and confused in these cases, a point to be addressed when discussing peace negotiations in Rwanda and Burundi.

\section{The Road to Arusha: Brief Histories of post-independence Rwanda and Burundi}

Rwanda received independence from Belgian colonial rule on July 1, 1962. Ethnic history in Rwanda began with German (1884-1926) and then Belgian (1926-1962) colonization as these colonial states converted previous socio-economic divisions within the country into ethnic identities with the minority Tutsi (15 percent of the total population) dominating over the majority Hutu population

\footnotetext{
${ }^{2}$ Hugo Slim, review of On Complicity and Compromise, by Chiara Lepora and Robert E. Goodin, Ethics E International Affairs 27, no. 4 (2014).

${ }^{3}$ Slim, On Complicity.

${ }^{4}$ Oliver Richmond, A Post-Liberal Peace (London: Routledge, 2012), 1-21.
} 
(84 percent of the total population) as well as the relative few Twa residence population (only composing 1 percent of the total population). ${ }^{5}$ Ethnic dominance was transferred away from Tutsis to Hutus during independence with the development of an extremist Hutu counter-elite that gained control of government in 1959 with the development of the PARMEUTU political party. Thousands of Rwandan Tutsis fled into neighboring countries. Pogroms, massacres, and forced immigration of mostly Tutsis led to an estimated 120,000 Rwandans to flee from Rwanda. Many of their children would later create the Rwanda Patriotic Front (RPF), which would ignite the Rwandan Civil War (1990-1994), enter negotiations and accept the terms of the Arusha Accords (1993), end the Rwandan Genocide (1994), and dominate the current Rwandan government.

During the early years of the exile, many refugees hoped for international involvement to solve their status by applying pressure on the post-independence government of Grégoire Kayibanda (1962-1973). However, the international community abandoned the refugee cause with the disappointment of the United Nations becoming a norm. From our interviews, Rwandan refugees illustrated the distrust and feeling of abandonment by the United Nations by using the United Nations as a type of lullaby sung to children. They would even call a lazy person 'someone who works for the UN. ${ }^{\prime}$ With international abandonment being accepted as the norm, many Rwandan refugees crafted ideologies to fit alongside the desire to return.

The establishment of the Rwanda's Alliance for National Unity (RANU), which later became the RPF, crafted the Eight-Point-Programme that called for a "one Rwanda" ideology rather than a nation of ethnic divisionism. ${ }^{7}$ The refugees' desire to return to Rwanda led to the Rwandan Civil War beginning on October 1, 1990 with the RPF's military wing, the Rwandan Patriotic Army (RPA) invading the country from its Ugandan border. ${ }^{8}$ The initial invasion failed with a combination of French intervention and the death of RPA leader, General Fred Rwigyema. ${ }^{9}$ With the failed invasion, the RPA were able to recuperate after moving into the Virunga Volcano forest, which was adjacent to the politically influential city of Musanze. The city was at the heart of President Juvenal Habyarimana's political base. On January 24, 1991, the RPA raided Musanze for military equipment, food, as well as freeing political dissidents held in the city's jails. ${ }^{10}$ The main goal of the surprise attack was the desire to showcase to the Habyarimana regime as well as the international community that the RPF was not defeated after the failed first invasion attempt and was going to continue to fight for the right of return for Rwandan refugees.

International pressure from Uganda, Belgium, United Kingdom, United States, and even Habyarimana's European ally of France, forced the Rwandan government to begin negotiations with the RPF on August 10, 1992. ${ }^{11}$ Negotiations originally were initiated by political opposition parties of Habyarimana, the Democratic Republican Movement (MDR), Social Democratic Party (PSD) and the Liberal Party (PL), the government eventually took part. ${ }^{12}$ As the Habyarimana regime began serious negotiations with the RPF, the initial parties were sidelined as they could not enforce any concessions given to the RPF. Negotiations were difficult as the RPF demanded for

\footnotetext{
${ }^{5}$ Stephen Kinzer, A Thousand Hills, Rwanda's Rebirth and the Man Who Dreamed It (Hoboken: John Wiley \& Sons, Inc., 2008), 24; Gerard Prunier, The Rwanda Crisis: History of a Genocide (New York: Columbia University Press, 1995), 5-9.

${ }^{6}$ Tito Rutaremara (Rwandan Senator) in discussion with Jonathan Beloff, July 27, 2014.

${ }^{7}$ Patricia Crisafulli and Andrea Redmond, Rwanda, Inc.: How a Devastated Nation Became an Economic Model for the Developing World (New York: Palgrave Macmillan, 2012), 52, 62; Kinzer, A Thousand Hills, 50-52; Prunier, Rwanda Crisis, 72-75, 81; Frank Rusagara, “The Spread of the 'Genocide Ideology' Within the Great Lakes Region: Challenges for Rwanda," in Rwanda Fast Forward: Social, Economic, Military, and Reconciliation Prospects, ed. Maddalena Campioni and Patrick Noack (New York: Palgrave Macmillan, 2012), 187.

${ }^{8}$ Kinzer, A Thousand Hills, 56-58; Prunier, Rwanda Crisis, 97-100.

${ }^{9}$ Linda Melvern, A People Betrayed, The Role for the West in Rwanda's Genocide (London: Zed Books, 2000), 30, 181, 213-219; Johan Pottier, Re-imagining Rwanda: Conflict, Survival and Disinformation in the Late Twentieth Century (Cambridge, UK: Cambridge University Press, 2002), 36; Waugh, Paul Kagame and Rwanda: Power, Genocide, and the Rwandan Patriotic Front (Jefferson: McFarland \& Company, Inc., 2004), 46-47.

${ }^{10}$ Kinzer, A Thousand Hills, 85-89; Melvern, A People Betrayed, 241; Waugh, Paul Kagame and Rwanda, 53-54.

${ }^{11}$ Mahmood Mandani, When Victims Become Killers: Colonialism, Nativism, and the Genocide in Rwanda (Princeton, Princeton University Press, 2001), 210; Melvern, A People Betrayed, 52; Prunier, Rwanda Crisis, 108, 148-152; Waugh, Paul Kagame and Rwanda, 88-89.

${ }^{12}$ Mandani, When Victims Become Killers, 210.
} 
their inclusion in the government by being appointed ministers for five government institutions such as the Ministry of Youth and Culture and the Ministry of the Interior; composing of 40 percent of the Rwandan Armed Forces (FAR) both in terms of ground soldiers and officers; removal of French soldiers from Rwanda; implementation of a right of return for Rwandan refugees; ethnic labels removed from national identity cards as well as free elections after a twenty-two month period. ${ }^{13}$ Participants from extremists parties such as the Coalition for the Defence of the Republic (CDR) rejected multiple debated topics as well as continual negotiations with the Tutsi RPF. However, many RPF delegates such as Pasteur Bizimungu, Theogene Rudasingwas and Patrick Mazimpaka and Tito Rutaremara persisted in achieving their desired goals. Rutaremara recounts a major difficulty experienced during the negotiations. He describes how many of Habyarimana's representatives seemingly had little interest in negotiating, but rather to engage in other recreational activities. He illustrates this by describing what each party did after a day's negotiations:

The government of Rwanda (Habyarimana's delegates) would go drinking or partying after the day's negotiation. The RPF (delegates) instead would return to their rooms and work together on writing papers and notes of the day's events as well as new negotiating points that they wanted to discuss the next day. This added the RPF's negotiations, because when the government of Rwanda would complain and disagree, the RPF would demand to see their plans in writings, which they never had! $!^{14}$

Despite difficulties, the Habyarimana government accepted a peace deal (Arusha Accord) that would keep Habyarimana as President with his political party, the National Republican Movement for Democracy and Development (MRND(D)), maintaining significant government positions, but their power would be diminished and shared. More importantly, the RPF was able to achieve nearly all of their demands.

The Arusha Accord was finally signed on August 4, 1993 after renewed pressure on the Habyarimana regime by a return to fighting by the RPF ${ }^{15}$ in January $1992 .{ }^{16}$ The peace agreement introduced a sense of relief for many who believed that ethnic conflict, whether between major actors such as the Rwandan Government and the RPF or more general such as Rwandan Hutus and Tutsi, would reduce and not lead to a larger mass murder. One Rwandan civilian accused of being an RPF spy in Kigali commented, "we thought the war was done. We (living in Kenya after the 1992 fighting) returned home thinking that Rwanda moved from its killing. There was such a sense of hope for tomorrow."17 For civilians wanting an end to the violence, the agreement indicated possible peace and preventing future massacres. While few would predict a genocide erupting if conflict continued, there was a sense that the Arusha Accords prevented the nation from slipping into chaos. For many within the RPF, this was a sign of victory of their quest for the right of return for Rwandan refugees as well as transforming Rwandan society into their 'one Rwanda' ideology. Many RPF and former RPA officials viewed the accord as a great victory at the time and believed that with the inclusion of a United Nations peacekeeping force, United Nations Assistance Mission in Rwanda (UNAMIR), the international community would no longer abandon Rwanda and its refugees.

However, upon later reflection, many within the current Rwandan Government acknowledge that the accords would not be enough to prevent the impending genocide. One Rwanda Defense Force $^{18}$ (RDF) commander reflected on Arusha, "we thought we had won, because we got everything we asked for! It was a dream, but looking back now, we know it was useless." ${ }^{19}$ His

\footnotetext{
${ }^{13}$ Kinzer, A Thousand Hills, 107-108.

${ }^{14}$ Tito Rutaremara (Rwandan Senator) in discussion with Jonathan Beloff, August 27, 2014.

${ }^{15}$ The RPF broke the previously agreed cease-fire after 300 Rwandans were killed by Hutu extremists.

${ }^{16}$ Melvern, A People Betrayed, 49, 62-63; Prunier, Rwanda Crisis, 174.

${ }^{17}$ Unnamed Rwandan (retired office worker) in discussion with Jonathan Beloff, June 2012.

${ }^{18}$ In 2002, the Rwanda Patriotic Army changed its name to the Rwanda Defence Force.

${ }^{19}$ Unnamed Rwandan (military official) in discussion with Jonathan Beloff, November 2014.
} 
reflection was similar to Rutaremara's who heard at the end of the signing of the accord's Rwandan military commander Colonel Theoneste Bagasora's infamous words of, "preparing the second apocalypse." ${ }^{20}$ Bagasora's comments were a direct reference to the preparation of the upcoming genocide that took place only nine months later. Reyntjens, ${ }^{21}$ Prunier, ${ }^{22}$ and Guichaoua ${ }^{23}$ question RPF commitment to the accords as it was unlikely the RPF could win a majority in an election, as many Rwandans feared or held negative opinions of the RPF. Thus, only through military means could the RPF take control over the government. Dallaire ${ }^{24}$ dismissed this assumption by stating how the RPF was in full support of the accord. The Arusha Accords might have brought a temporary peace and prospects of the end of the ethnic conflict. However, it only provided the space and timing for genocidaires to prepare for their massacres. The failures of the accord would affect how the RPF would perceive international engagement and corporation.

The history and culture of Rwanda and Burundi are inexorably linked, and the violence of the 1990s through the present is often treated as having stemmed from the same problems. However, post-independence violence and ethnic ideology developed differently in Rwanda and Burundi. ${ }^{25}$ At the time of independence, also in July 1, 1962, the Burundian population was composed of a similar ethnic makeup as Rwanda, 84 percent of the total population were identified as Hutu, 15 percent as Tutsi, and less than 1 percent as Twa. ${ }^{26}$ Popular assumption implies the patterns of and rationale for violence in both countries were virtually the same. However, in Rwanda, policies of ethnic divisionism fuelled conflict, whereas in Burundi, the suppression of ethnic identity led to a state of fear and uncertainty, leading to conflict there, as well.

Scholars, including Prunier ${ }^{27}$ Fujii, ${ }^{28}$ Straus and Waldorf, ${ }^{29}$ Uvin, ${ }^{30}$ Lemarchand, ${ }^{31}$ David and Catherine Newbury, ${ }^{32}$ and Ndikumana ${ }^{33}$ address the history and salience of ethnicity in Rwanda and Burundi, in addition to themes of ethnicization of politics, institutional capacity, and historical memory as factors that impacted violence in both countries. After independence, unlike in Rwanda, the monarchy in Burundi survived, resulting in a bi-ethnic party, UPRONA (Union Pour Progrès National), led by Prince Louis Rwagasore, who was elected after independence. Rwagasore was assassinated in October 1961, thus thrusting the political party toward internal conflict. Fighting for control of the state took place between the Tutsi-Hima, Tutsi-Banyaruguru, and a small emerging Hutu elite, where the Tutsi-Hima emerged successfully. In addition, following the Social Revolution in Rwanda, state control became the sole vehicle for Tutsi to retain their privileges in Burundi. Instead of the reinforcement of a single-ethnic country, as in Rwanda after independence, Burundian elites officially stated that ethnicity was not as important as other social factors, but underneath the official rhetoric the structural violence of ethnic identity and ethnic clientship remained.

Differences in ethnic divisions fueled competition for state power in Rwanda and Burundi, yet leadership differed in the two. Both countries sought a small elite backed by military support to

\footnotetext{
${ }^{20}$ Romeo Dallaire, Shake Hands with the Devil: The Failure of Humanity in Rwanda (New York: Da Capo Press, 2003), 291; Kinzer, A Thousand Hills, 110-111.

${ }^{21}$ Filip Reyntjens, Political Governance in Post-Genocide Rwanda (New York: Cambridge University Press, 2013 ), 7.

${ }^{22}$ Prunier, Rwanda Crisis.

${ }^{23}$ Andre Guichaoua, From War to Genocide: Criminal Politics in Rwanda, 1990-1994 (Madison: The University of Wisconsin Press, 2015), 67-76.

${ }^{24}$ Dallaire, Shaking Hands with the Devil, 66.

${ }^{25}$ Leonce Ndikumana, "Institutional failure and ethnic conflicts in Burundi," African Studies Review 41, no. 1 (1998), $29-47$.

${ }^{26}$ Ndikumana, Institutional Failure, 29-47.

${ }^{27}$ Prunier, The Rwanda Crisis.

${ }^{28}$ Lee Ann Fujii, Killing Neighbors: Webs of Violence in Rwanda (Ithaca: Cornell University Press, 2009).

${ }^{29}$ Scott Straus and Lars Waldorf, eds. Remaking Rwanda: State Building and Human Rights After Mass Violence (Madison: University of Wisconsin Press, 2011).

${ }^{30}$ Peter Uvin, "Prejudice, Crisis, and Genocide in Rwanda," African Studies Review 40, no. 02 (1997), 91-115.

${ }^{31}$ Rene Lemarchand, The Dynamics of Violence in Central Africa (Philadelphia: University of Pennsylvania Press, 2009).

${ }^{32}$ Catherine Newbury and David Newbury, "The Crisis in Rwanda. ASA News," African Studies Association 27, no. 3 (1994), 9-11.

${ }^{33}$ Ndikumana, Institutional Failure, 29-47.
} 
control the rest of the population. In Rwanda, it was the Hutu counter-elite; in Burundi it was the Tutsi elite, which garnered support from both Hutu and Tutsi citizens post-independence.

The Rwandan independence revolution, which elected Gregoire Kayibanda and the PARMEHUTU extremist regime, caused fear in Burundi, where both ethnic groups felt they needed to gain power at the other's expense. Political and ethnic groups were concerned about the conflict between Hutu and Tutsi taking place in Rwanda, and ethnic solidarity seemed too idealistic. This was a divorce from the rhetoric of ethnic solidarity and unity that had taken place before in Burundi, during the time of Price Rwagasore. Displaced Tutsi refugees arrived in Burundi from northern Rwanda and caused heightened mistrust and unease between Hutus and Tutsis. From 1965-1973, two-sided violence continued between Hutu and Tutsi political parties that trickled down to local violence among people of differing ethnicities. This stemmed from fear in the region, and knowledge of the impact that Hutu extremist rule had on Rwandan society. ${ }^{34}$

The Kayibanda and Habyiramana regimes created conflict by forming strong central governments that were highly ethnicized, which promoted hate propaganda against the Tutsi. These regimes made ethnicity the most important identity marker in terms of economic, social, and political opportunities in the country. ${ }^{35}$ In Burundi, the idea of oneness was reinforced among Burundian leaders, even though political elites practiced ethnic discrimination. Therefore, ethnicity existed and was salient, but ethnic affiliation was silenced to promote an air of social cohesion. According to Ndikumana, political elites in Burundi tell "half-truths"36 to the public about the causes and continuation of the massacres and conflict. ${ }^{37}$ This stems from an unequal distribution of power along ethnic lines, with minority Tutsi leadership in a majority Hutu country.

While discussion of ethnicity was stifled in Burundi for many years during Tutsi military coups from 1963-1993, after the assassination of Melchior Ndadaye in 1993, the country's first Hutu leader, ethnicity became a salient factor in political discussions. ${ }^{38}$ The resulting imbalance of power initiated by the colonial regime, Ndikumana says, has been maintained by the post-colonial governments in Burundi, and is an important cause of the violence that has existed in Burundi since the 1960s.

Rwanda and Burundi have different processes of ethnicization of politics, which have developed in reaction to initial ethnic policies and violent regimes in the two countries. In Burundi, although the importance of ethnicity is felt and grievances against the violence committed by "the other" is present in the minds of Burundians, there is nearly no forum to openly discuss violence of Hutus toward Tutsi, and violence of Tutsi toward Hutu. The Burundian government has sponsored propaganda in different spaces, including in the media and in academic institutions, to blame ethnicity on colonial imperialism. The propaganda also states that ethnic identity should not matter, and was a plot of the colonialists to create conflict in the country, to keep the Burundians repressed. According to the Burundian government, discussing ethnicity was deemed as a threat to national security. ${ }^{39}$

In addition, perception of the other and the neighboring country's struggles influenced the ethnicization of politics and how the main government acted. Tutsi leaders in Burundi used the example of massacres and violence in Rwanda leaders to develop a widespread fear of Hutu extremism among citizens of Burundi. This also resulted in anti-Hutu violence as fear escalated and desire to control the political situation and ensure Tutsi safety grew.

While ethnicization of politics stemmed from colonial focus on ethnic divisions, elites from both ethnicities in Rwanda and Burundi continued this system to wield power in their favor. The conflict over power affected nearly all citizens in both countries, and also perpetuated myths and

\footnotetext{
${ }^{34}$ Ravi Bhavnani and David Backer, "Localized Ethnic Conflict and Genocide Accounting for Differences in Rwanda and Burundi," Journal of Conflict Resolution 44, no. 3 (2000), 283-306.

${ }^{35}$ Scott Straus, The Order of Genocide: Race, Power, and War in Rwanda (Ithaca: Cornell University Press: 2006).

${ }^{36}$ Ndikumana, Institutional Failure, 29-47.

${ }^{37}$ Ibid.

${ }^{38}$ Villia Jefremovas, "Treacherous waters: the politics of history and the politics of genocide in Rwanda and Burundi," Africa 70, no. 2 (2000), 298-308.

${ }^{39}$ Ndikumana, Institutional Failure, 29-47.
} 
propaganda about "the other." In Rwanda, this was primarily used by Hutu extremist government, targeted at Tutsi citizens inside the country and the RPA/RPF Tutsi refugees in Uganda. In Burundi, however, the power and ethnicization of politics takes on a two-sided role. According to Uvin:

From 1966 to 1993 political and by extension economic power in Burundi was tightly held by three military regimes (Micombero, 1966-82, Bagaza, 1982-87, Buyoya 1987-93) that used their military might to keep their privileges. All three presidents were Tutsi-Hima from the same village in the Bururi region, born within two miles of each other. ${ }^{40}$

At the assassination of the first democratically elected Hutu President of Burundi, Melchior Ndadaye in October 1993, civil war broke out and the situation in Burundi deteriorated into total violence. ${ }^{41}$ During the civil war, Hutu lived in constant fear of revenge violence by the army and the militia after the massacres of 1972. Hate propaganda was a prominent form of inciting and motivating violence. According to Uvin, The Hutu inhabitants of Bujumbura, the capital, have largely been chased out of the city due to a policy reminiscent of the "ethnic cleansing" in the former Yugoslavia. ${ }^{42}$

The end of the civil war in Burundi concluded on August 28, 2000, when Burundian political parties signed the "Arusha Peace and Reconciliation Agreement for Burundi" (the Arusha Agreement) under the South African President Nelson Mandela, the negotiator of the Accords, although, like in Rwanda in 1993, violence was still occurring on the ground. According to the International Crisis Group:

The agreement was not really a peace agreement: it was a deal between the government and political parties, and it urged armed groups, which did not initially sign it, to suspend hostilities and negotiate a ceasefire. It was a manifesto for a possible return to peace, including long passages on how to reorganize the security forces, which had been responsible for much of the violence in the 1990s. It included a commitment to tackle the conflict's root causes, which the agreement presciently noted were "fundamentally political" and "stem from a struggle by the political class to accede to and/or remain in power." ${ }^{\prime 3}$

The Arusha Accords attempted to address two main issues, first guaranteeing political parity and full participation by the Tutsi minority and Hutu majority, and second how to rebuild trust of Hutu majorities in the armed forces ${ }^{44}$ This resulted in four main agenda items: 1 . A power sharing formula was created based on minority over-representation and coalition-building; 2. Protocols provided for the equitable participation of all parties in the three branches of government and in all national institutions including state-owned corporations; 3 . Constitutional checks to discourage the concentration of power by a single party or group of aligned parties; 4 . Modalities to integrate former enemies into a more representative military. ${ }^{45}$ As a result, these provisions were written into Burundi's constitution. Accordingly, no single ethnic group holds more than 50 percent of the defense and security forces. Similarly, no ethnic group holds more than 67 percent of local, county and municipal positions. However ideal the power-sharing agreement was, as ethnicity remained central to the identities of those in power, the failure of Arusha was partly due to the continuation of identity-based politics, including entitlement and exploitation of local civilians, the military, the

\footnotetext{
${ }^{40}$ Peter Uvin, "Ethnicity and power in Burundi and Rwanda: Different paths to mass violence," Comparative Politics (1999), 253-271, 257.

${ }^{41}$ Uvin, Ethnicity and Power, 257.

${ }^{42}$ Ibid.

43 "Insights from the Burundian Crisis (III): Back to Arusha and the Politics of Dialogue," International Crisis Group, last modified July 7, 2016, accessed October 26, 2018, https://www.crisisgroup.org/africa/central-africa/burundi/insightsburundian-crisis-iii-back-arusha-and-politics-dialogue.

${ }^{44}$ Paul Nantulya, "Why the Arusha Accords Are Central," Spotlight, Africa Center for Strategic Studies (2015), accessed October 26, 2018, https://africacenter.org/spotlight/burundi-why-the-arusha-accords-are-central/.

${ }^{45}$ Nantulya, Why the Arusha Accords Are Central.
} 
judiciary, and other politicians along in-group lines. Despite a well-designed structure, over time, the pervasiveness of identity-based politics allowed for abuse of power and an ultimate return to violence by calling upon and reviving these same factors that aimed to protect the population from such violence in the first place.

\section{Revolutionary Rapprochement: Non-state Movements and Arusha}

Arusha Arises in Rwanda

The failure of the 1993 Arusha Accord in Rwanda is perhaps most understood by the onset of the 1994 genocide. There were multiple events before, during, and after the genocide that signaled the accords were unable to help fulfill its intensions. Prior to the genocide, the Habyarimana regime increased in political space in July 1991, as a response to economic recession, international pressure, and the RPF. ${ }^{46}$ It was not the RPF that sparked the initial challenge to Habyarimana's rule, but rather economic factors. The decline of tea and coffee prices, the main exports of Rwanda, forced the government to ask for additional loans and increases in foreign aid and debt forgiveness. French President, François Mitterrand, the United States, and other Western nations pressed African countries, including Rwanda, to open their political space in return for continual or increased assistance. ${ }^{47}$ This international call was coupled with an increase in domestic pressure with tens of thousands protesting Habyarimana's one-party rule in January $1992 .{ }^{48}$ Scholars such as Prunier, ${ }^{49}$ Kimonyo, ${ }^{50}$ Melvern, ${ }^{51}$ Guichaoua, ${ }^{52}$ and others write extensively of how the opening of political space provided the foundations for Hutu extremists parties such as the CDR in 1992 alongside with the extremist elements of Habyarimana's MRND(D) to thrive and garner support. The opening of political space leading to Hutu extremism influenced RPF leaders after the genocide to restrict political space in order not to permit renewed extremism. The Arusha Accords, while continuing to open political space, also granted the environment for Hutu extremist parties to prepare for the immediate days after the start of the genocide by overthrowing the transitional government headed by Prime Minister Agatha Uwilingiyimana ${ }^{53}$ and forcing other political moderates such as Faustin Twagiramungu and Seth Sendashonga to flee into UNAMIR protected zones. These events influenced RPF officials after the genocide to restrict public space in order to prevent a repetition of the accord's unintentional allowance of space for extremists.

While the Arusha Accords began to fail prior to the genocide, its ultimate failure was the prevention of a continuation of the Rwandan Civil War and genocide. Most notable is how the accord seemed to foster genocide ideology by granting it the space to thrive through weakening the current structures that promoted a less, but still extreme, prejudice against the Rwandan Tutsi population. The assassination of Habyarimana on 6 April, 1994 by some unknown force triggered the beginning of the genocide. ${ }^{54}$ While some such as Reyntjen $s^{55}$ believe the RPF to be responsible for the assassination, it seems much more probable the attack was committed by the Hutu extremists' groups angry at Habyarimana for agreeing to the accord and fearing its full implementation..$^{56}$ The ultimate failure of the accord is best summarized with RPA leader, General Paul Kagame refusing

${ }^{46}$ Prunier, Rwanda Crisis, 127-150.

${ }^{47}$ Robert Gribbin, In the aftermath of genocide: The US role in Rwanda (Lincoln: iUniverse, 2005), 46; Kinzer, A Thousand Hills, 54, 77-79, 92-95; Melvern, A People Betrayed, 43-49, 55, 66-68; Prunier, Rwanda Crisis, 90-99; 159-160.

${ }^{48}$ Kinzer, A Thousand Hills, 103; Prunier, Rwanda Crisis, 134-135.

${ }^{49}$ Prunier, Rwanda Crisis, 150-158.

${ }^{50}$ Jean-Paul Kimonyo, Rwanda's Popular Genocide: A Perfect Storm (London: Lynne Rienner Publishers, 2016), 84-86.

${ }^{51}$ Melvern, A People Betrayed, 39-69.

${ }^{52}$ Guichaoua, From War to Genocide, 62-105.

${ }^{53}$ She was a member of the more moderate Republican Democratic Movement (MDR). She was killed on 7 April 1994 by the Presidential Guard.

${ }^{54}$ Kinzer, A Thousand Hills, 1; Pottier, Re-imagining Rwanda, 30-35; Prunier, Rwanda Crisis, 213.

${ }^{55}$ Jane Corbin Rwanda's Untold Story (2014; London: BBC Two), Television series episode, accessed October 26, 2018, http:// www.bbc.co.uk/programmes/b04kk03t.

${ }^{56}$ Jonathan Beloff, “Lies We Encounter when Facing Genocide Denial," Times of Israel, October 2, 2014, accessed November 3, 2016, http://blogs.timesofisrael.com/hitlers-jewish-background-and- other-lies/. 
to negotiate with the interim-government, who were conducting the genocide, until they ended the massacres and instead deciding to disregard the accord and restart the war to force them out of power. ${ }^{57}$ The justifiable causes of Kagame's desire not to hold dialogue stemmed from the agaciro belief that only through self-responsibility and self-reliance, especially on the part of the interim government, could the genocide end.

Humanitarian intervention was minimal during most of the genocide. At the beginning of the genocide, UNAMIR commander General Roméo Dallaire had only 2,548 troops to try to stop the massacres and save civilians. However, this number decreased to only 270 on April 21, after UN Security Council passed Resolution 912 to minimize UNAMIR's capabilities. ${ }^{58}$ Following the collapse of the Arusha Accords, Rwanda was abandoned by the international community and between 800,000 to one million Rwandan Tutsi and moderate Hutus died between April 6 to July 19, 1994. The genocide was a major turning point in how the RPF viewed domestic and international engagement.

Little of the pre-genocide multiparty government remained. The RPF political delegates bunkered at the Parliament building in Kigali survived because of the protection of 600 stationed RPA soldiers. ${ }^{59}$ Within the first three days of the genocide, Hutu extremists targeted and assassinated oppositional political leaders. Some members had survived such as Faustin Twagiramungu, but most other political officials were killed.$^{60}$ Despite a lack of political leaders and the introduced ban on the CDR and MRND(D), the RPF, who were the only surviving political organization and whose armed wing ended the genocide, brought back the Arusha Accord as the central legal doctrine alongside the previous 1991 Constitution. On July 19, the new post-genocide government was sworn in with much of the accord being implemented. However, there were two major differences. As Prunier describes: first, political seats designated to the now banned political parties were taken by the RPF ${ }^{61}$ However, this was quickly criticized by the remaining parties. Thus, each of the political parties received either one or two additional ministerial seats. Second, the President and the newly created Vice-Presidential positions were created and filled by RPF officials, Pasteur Bizimungu and Paul Kagame respectively. However, the lack of developed opposition parties allowed the RPF to cement its current rule over Rwanda.

The new implementation of the Arusha Accords faced serious problems and seemingly ended within two years after the genocide. While it no longer provided the space for Hutu extremists to develop and conduct genocide, it did not establish a continual Rwandan Government with functioning and diverse political parties. The intended political outcomes from the Arusha Accords was short lived. The broad government consisting of the RPF and other moderate parties quickly collapsed as many non-RPF Government officials felt that they were being by-passed by RPF members for new government positions. Additional claims of harassment by RPF and Tutsi officials against non RPF or Hutu Government officials led to many leaving the transitional government. ${ }^{62}$ This indicates how RPF leaders were attempting to form a government run solely by RPF members. This assessment contradicts Gribbin's experiences working in Rwanda where he states of Bizimungu and Kagame's desire to fulfill the accord. ${ }^{63}$ The Kibeho massacre, which witnessed an estimated $5000^{64}$ predominately Hutu civilians massacred by RPA forces on April 22, 1995, was the end for the accord's desire of a multiethnic and multi-party government. ${ }^{65}$ It resulted

\footnotetext{
${ }^{57}$ Dallaire, Shake Hands with the Devil, 246-248; Kinzer, A Thousand Hills, 148-168.

${ }^{58}$ Dallaire, Shake Hands with the Devil, 236, 245-246, 268; Melvern, A People Betrayed, 152-166; Prunier, Rwanda Crisis, 192197, 234-235, 275.

${ }^{59}$ Dallaire, Shake Hands with the Devil, 126-127; Kinzer, A Thousand Hills, 122-123; Prunier, Rwanda Crisis, 204; Waugh, Paul Kagame and Rwanda, 63.

${ }^{60}$ Prunier, Rwanda Crisis, 231.

${ }^{61}$ Ibid., 329.

${ }^{62}$ Ibid., 330 .

${ }^{63}$ Gribbin, In the Aftermath of Genocide, 121, 149-158.

${ }^{64}$ The official Rwandan Government death count was 338.

${ }^{65}$ Lemarchand, The Dynamics of Violence, 64, 73-75; Pottier, Re-imagining Rwanda, 98, 161; Gerard Prunier, Africa's World War Congo, The Rwandan Genocide, and the Making of a Continental Catastrophe (New York: Oxford University Press, 2009), 38.
} 
in the resignation of Prime Minister Faustin Twagiramungu, Interior Minister Seth Sendashonga (one of the few RPF Hutu members) and Justice Minister Alphonse Nkubito in August 1995. ${ }^{66}$ The Arusha Accord would be replaced with a RPF-dominated Rwandan government with the RPF believing that negotiating and cooperating with domestic and foreign actors unwise. Rather, it alone needed to lead the state in its social, political and economic development in order not to repeat the events that led to the genocide.

\section{Arusha Arises in Burundi}

The strategy of the main mediator for the Arusha Accords in Burundi, Nelson Mandela, was similar to that in Rwanda, where the RPF, as a liberation party was engaged throughout the Arusha process, with the goal of being integrated into the political system as an official political party. Mandela's decision to reengage the more moderate of extremist parties in Burundi, the CNDD. Although the CNDD did not take part in the drafting of the Arusha accord, during the Arusha negotiations the CNDD was led by Leonard Nyangoma. However, the CNDD fractured into two; thus, the creation of the CNDD-FDD by a faction of CNDD Nkurunziza after Arusha. Bringing in the CNDD, though, helped bring the spoilers to the negotiating table, ultimately resulting in an accord that was acceptable and passable for all parties involved. However, in the process of reengagement, the limitations of the CNDD became apparent. Unlike the RPF, they were not a liberation movement, and they lacked a coherent ideology for political advancement, leadership, and gain making. According to an interview with a regional expert on Peace and Security, working on issues in Burundi, "Liberation movements lacking a clear ideology often flip-flop and have trouble saying what they desire. They can be more of a liability if they don't have a clear vision or ideology." ${ }^{67}$ Yet, they used extremist tactics to undermine the process and threaten the Burundian population. According to the United States Government Definition of Violent Extremism, two components must be present: 1) methods of violence, and 2) ideology. Lacking ideology was a major weakness of the movement turned party. Mandela's team saw this, and he used the strategy of approaching these non-violent extremists as a way to engage and secure the CNDD during the negotiations.

Since Arusha, the newly formed CNDD-FDD has used a calculus of threat, morphing from a movement that seemed interested in reintegrating into the international community, to a radicalized party. It rests on tenets of the neocolonial narrative in Burundi, a narrative that is antiWestern, anti-African Union, and anti-ICC, where its calculus of threat and calculus of survival is operating more on a survival basis rather than a long-term plan.

The CNDD was a movement formed after the assassination of Melchior Ndadaye in 1993, who was the first democratically elected Hutu president in Burundi. Originally, the CNDD-FDD was based on goals to rid the military and intellectual society of Hutu intellectuals and military leaders, in the 1960s and 1970s. However, over time and after the failed Hutu coup and subsequent violence against Hutu citizens in Burundi in 1972, the CNDD-FDD lost its ideological basis. After engaging in the Arusha process with mediator Nelson Mandela, the CNDD-FDD, now as an official political party, won elections in 2005 according to the power-sharing outcomes and ideals of the Arusha accords. ${ }^{68}$ However, the pretense of a multi-ethnic movement changed over time, as well, and deteriorated after the 2010 and 2015 elections, when ethnic rhetoric and violence had been wielded against the citizenry, in a clear abandonment of Arusha's principles, thus, throwing the country back into daily violence and a mass atrocity situation. This was a calculation of party survival that undermined the goals of creating a stable political society and arrangement in Burundi despite ethnic tensions and legacies of two-sided violence.

The Arusha Peace and Reconciliation Agreement for Burundi had strong accountability mechanisms. However, the protagonists were keen to secure immunity from prosecution and so their implementation focused on power-sharing. This has given the government license to mobilize

\footnotetext{
${ }^{66}$ Filip Reyntjens, "Rwanda ten years on: From genocide to dictatorship," African Affairs 103, no. 411 (2004), 180.

${ }^{67}$ Nantulya, Paul, in discussion with the author. December 2015.

${ }^{68}$ Nantulya, Why the Arusha Accords Are Central.
} 
against the opposition with little fear of sanction. In the process, the government has been able to tighten its grip on power ${ }^{69}$ Finally, external guarantors of peace agreements often pull back from the post-conflict context and have been reluctant to hold signatories accountable when they violate terms of the agreement. Agreements in Burundi provided strong regional and international monitoring mechanisms. However, these were ultimately not consistently enforced. In Burundi, regional and international actors opted not to intervene during the run-up to the 2010 elections after there were clear signs that the situation there was going to deteriorate. The pattern of atrocities leading up to the 2015 elections was eerily similar, and again, there were no effective deterrents to such behavior.

\section{How Was Arusha Flawed? Contemplating the Outcomes of the two Arusha Accords in Rwanda and Burundi} Outcomes of Arusha in Rwanda: Peacekeeping, Ideology, and Ethnicity

The introduction of the 2003 Rwandan Constitution officially ended the Arusha Accord..$^{70}$ However, by this time the agreements in the deal were relatively ignored leaving the RPF in near complete control over the government. One Rwandan discussed the transition from the accord to the new constitution as, "Arusha gave us failed hope, but at least the RPF tried to implement it after the genocide. It helped guide us until we were ready to form our Constitution (in 2003)." ${ }^{71}$ After nearly twenty-four years from its signing, its legacy can still be seen through how Rwanda perceives and interacts with the international community. Additionally, the accord's failed desires for domestic political transition and preventing international abandonment of civilians has influenced how the Rwandan government perceives its commitment in peacekeeping. To properly establish Rwandan perceptions, it is necessary to revisit the RPF's understanding and expectation of the accord as well as past engagement with their adversaries, i.e. the Habyarimana regime, and the international community.

The RPF viewed the Arusha negotiations within its growing understanding of international order following what can be considered akin to the international relations theory of liberalism. At liberalism's core is the expectation that negotiations between leaders can attempt to prevent or stop certain conflicts and violence that are against universal norms. ${ }^{72}$ Many within the RPF and the RPA believed after the attack on Muzanse and the beginning of the Arusha process, that negotiations was an effective mechanism to achieve their goals. ${ }^{73}$ The genocide shattered the RPF's understanding of the international order operating within liberalism. Most problematic to their usage of liberalism was, not how negotiations resulted in genocide, but rather how universal norms of human rights were quickly ignored by the international community. It was only the RPF who put an end to the genocide with UNAMIR only providing minimal support to safeguard victims. While the international community historically ignored the plight of Rwandan refugees, mostly Tutsis, and as $\mathrm{Uvin}^{74}$ writes the situation of domestic Tutsis, international abandonment during the genocide undermined any belief that the world was concerned about human rights when conflicted with state security and interest. In response to Rwanda's abandonment and the RPF's responsibility, as the only entity willing to put an end to the massacres, ${ }^{75}$ realism took center stage as the dominant

\footnotetext{
${ }^{69}$ Samantha Lakin, Africa Center for Strategic Studies, "Q\&A: Lessons in Preventing Genocide in Africa since Rwanda," Spotlight, April 7, 2017.

${ }^{70}$ Margee M. Ensign and William Bertrand, Rwanda: History and hope. (New York: University Press of America, Inc, 2010), 50-51, 64-65; Anatasia Shyaka (CEO of the Rwanda Governance Board) in discussion with Jonathan Beloff, November $12,2014$.

${ }^{71}$ Unnamed Rwandan (retired office worker) in discussion with Jonathan Beloff, May 2013.

${ }^{72}$ Robert Jackson and George Sorensen, Introduction to international relations: Theories and approaches, 2nd ed. (Oxford: Oxford University Press, 2003), 128, 135-136; Stephan Krasner, International regimes (Ithaca: Cornell University Press, 1983), 2.

${ }^{73}$ Colonel Jill Rutaremara (Director of the Rwanda Peace Academy) in discussion with Jonathan Beloff, November 10, 2014.

${ }^{74}$ Peter Uvin, Aiding violence: the Development Enterprise in Rwanda (West Hartford: Kumarian Press, Inc, 1998), 181.

${ }^{75}$ General Joseph Nzabamwita (Secretary General of National Intelligence and Security Services) in discussion with Jonathan Beloff, May 2013.
} 
understanding by Rwandan officials of how the international system operates. Realism best explains why the international community kept supporting President Habyarimana negative public policies prior to the genocide because his regime was seen by the French government as part of their nation's sphere of influence and contained state interests. Senator Rutaremara extends Habyarimana's network to the United States. "The Government of Rwanda (Habyarimana regime) was an ally of France, which was ally of the United States, so why would the US government want to remove a regime that had great support by France?"76

Manager of the Kigali Genocide Memorial, Honore Gatera described the failures of the Arusha Accords as leading to the rise in realism;

I think you have to put it (the change by the RPF from a liberalist to realist perception of international affairs) into perspective. Many of us hoped that Arusha (accord) would work, but it did not and resulted in so many dead. The world left because (Rwanda) was not in their (state) interest. So, we realised that the world works based on interests and (the) power of nations. ${ }^{77}$

These perceptions follow alongside neoclassical realist writer Hans Morgenthau's interpretation of morality in the international community as, "Realism maintains that universal moral principles cannot be applied to the actions of states in their abstract universal formulation, but that they must filtered through the concrete circumstance of time and place."78 The Arusha Accords created a sense within Rwanda and the RPF of how the international community, which pushed Habyarimana into negotiations, acceptance and enforcement of the accord, believed in a sense of morality that included preserving human rights. However, the inactions by the international community to stop the killings, as seen with the withdrawal of UNAMIR peacekeepers, implanted a perception of how state interests and power rather than moral consideration exists within the international order. This reality still holds true for many within the current RPF-dominated Rwandan government.

Despite realism being the dominate theory underlying Rwandan perceptions of the international system, some liberalism stemming from the Arusha period still persists. The liberal belief of universal human rights is still held by Rwandan government elites in how they set foreign policy, including participation in regional and global peacekeeping missions. Rwanda participates in peacekeeping operations in Central African Republic (CAR), South Sudan, Darfur (Sudan), Haiti, and Mali, as well as in other conflict zones. ${ }^{79}$ RDF Chief of Staff, Patrick Nyamvumba, described the different reasons for why Rwanda participates in peacekeeping missions that both incorporate elements of realism, but also include past experiences with the failed UNAMIR mission. He says, "we deploy peacekeepers with three ideas. First, (fostering) peace resolution for local and regional interests. Most of Rwanda's peacekeepers are stationed in the region. Second, a secure environment in the region helps Rwanda. And third, participate because of the international community as a backdrop." ${ }^{80}$ The first reason relates to human rights views held by Rwandan officials who held similar views during the signing of the accords. The last reason directly relates to Rwanda's past experiences and its responsibility to prevent other countries from experiencing what Rwanda experienced. Both these reasons share a common desire for the protection of human rights in conflict situations that were previously held by RPF negotiators during the formulation of the Arusha Accords. The failure of the accord and of the international community to defend these rights during the genocide influences Rwandan policy makers in how its own military is used in peacekeeping missions.

\footnotetext{
${ }^{76}$ Tito Rutaremara (Rwandan Senator) in discussion with Jonathan Beloff, August 27, 2014.

${ }^{77}$ Honore Gatera (Director of the Kigali Genocide Memorial) in discussion with Jonathan Beloff, September 11, 2014 and September 6, 2016.

${ }^{78}$ Jackson and Sorensen, Introduction to international relations, 78.

${ }^{79}$ The Permanent Mission of Rwanda to the United Nations, "UN peacekeeping," 2014, accessed November 3, 2016, http:// rwandaun.org/site/un-peacekeeping.

${ }^{80}$ General Patrick Nyamvumba (Rwanda Defence Force Chief of Staff) in discussion with Jonathan Beloff, September 11, 2014.
} 
Beswick, ${ }^{81}$ Fisher ${ }^{82}$ Zorbas, ${ }^{83}$ and Reyntjens ${ }^{84}$ differ from this explanation of Rwanda's participation in peacekeeping. Instead, they comment on how it is a mechanism to gain favor from Western states and/or to deflect criticism. Their assumptions can be applied to General Nyamvumba's first reason for Rwandan participation in peacekeeping. However, Rwandan perception of state interest is different from the current literature. Instead of promoting state interest through a secure regional neighborhood, these scholars suggest that Rwanda primarily participates in peacekeeping for broad international and mostly Western states, such as the United States, United Kingdom, and the European Union, for political or financial reasons. These assumptions are problematic for Rwandan officials. Defence Minister, James Kabarebe, disagrees with this explanation by illustrating how Rwandan troops are sent to nations close to or already experiencing genocide rather than other missions that might be more favourable to the West. He explains: "if it did (Rwanda participating in peacekeeping missions to satisfy global attention on conflict states connected to Islamic terror), if Rwanda was just sending troops for foreign policy advantages, then why have the RDF not sent troops to Somalia? Instead, the RDF sends troops when they fear genocide is going to afflict a country." ${ }^{85}$ Rwanda's drive towards participation in peacekeeping missions includes the desire to help prevent or stop other nation's experiencing genocide. Secretary General of National Intelligence and Security Services, General Joseph Nzabamwita, describes the connection between Rwanda's participation of peacekeeping with combating genocide, "With the international community's injustices in the past when it comes to Rwanda and peacekeeping (UNAMIR's inactions), Rwanda wanted to be different and challenge the narrative of what the UN has done in the past without just criticism of the institution." ${ }^{\prime 86}$ Nzabamwita's mention of UNAMIR connects directly with perceptions of how the Arusha Accord failed to protect Rwanda. The current Rwandan government and military are, thus, still affected by the failure of the accords to promote peace. This is best seen by how Rwanda does not want to abandon other states by allowing their accords to fail.

Outcomes of Arusha in Burundi: Hardened Ideology, Ethnicity, and Cycles of Institutional Failure Though flawed in implementation, Arusha was historically significant because of its attempts to end violence on the ground in Burundi and create a system for post-civil war political and social arrangements in Burundi. Two world-class mediators, Nelson Mandela and Julius Nyerere, played key roles in including and engaging the CNDD-FDD in the negotiations, which ended up being successful in the short-term to end the civil war. However, 15 years after the conclusion of the Arusha negotiations in Burundi and the inclusion of the CNDD-FDD and Pierre Nkurunziza into the official governmental sphere, respect for term limits and rule of law have gone awry. As was seen in Rwanda in 1990-1994, genocidal rhetoric has resurfaced and daily massacres have resumed. The goal is to use ethnic politics to motivate a young, frustrated, impoverished, and hopeless population into the trenches of war to gain what the government cannot legitimately provide. ${ }^{87}$

Due to problems with the 2010 and now 2015 elections, the Arusha agreement has essentially been replaced by a de facto one-party system. This has resulted in an end to most dialogue between the opposition and the ruling party and has shifted the government into an authoritarian spiral

\footnotetext{
${ }^{81}$ Danielle Beswick, "Peacekeeping, Regime Security and 'African Solutions to African Problems': Exploring motivations for Rwanda's involvement in Darfur," Third World Quarterly 31, no. 5 (2010), 739-754; Danielle Beswick, "The Risks of African Military Capacity Building: Lessons from Rwanda," African Affairs, 113 no. 451 (2014), 212-231.

${ }^{82}$ Jonathan Fisher, "Managing donor perceptions: Contextualizing Uganda's 2007 intervention in Somalia," African Affairs 111 no. 444 (2012), 422-423; "Structure, agency and Africa in the international system: Donor diplomacy and regional security policy in East Africa since the 1990s," Conflict, Security \& Development 13, no. 5 (2013), 538-539, 553-560.

${ }^{83}$ Eugene Zorbas, "Aid dependence and policy independence: Explaining the Rwandan paradox," in Remaking Rwanda: State Building and Human Rights after Mass Violence, ed. Scott Straus and Lars Waldorf (Madison: The University of Wisconsin Press, 2011), 112.

${ }^{84}$ Reyntjens, Political Governance, 72-73.

${ }^{85}$ James Kabarebe (Former Rwandan Defence Minister) with Jonathan Beloff, September 13, 2014.

${ }^{86}$ General Joseph Nzabamwita (Secretary General of National Intelligence and Security Services) in discussion with Jonathan Beloff, September 2, 2014.

${ }^{87}$ Kaneza, Carine, in discussion with the author. October 2016.
} 
where violence is used to wield power and legitimacy. Challenged by armed groups and criticized by civil society and the international community, the government has resorted to repression and intimidation. ${ }^{88}$

Institutional failure in Rwanda and Burundi also helps explain the deterioration of power politics and ethnic manipulation into violence. Ndikumana writes that in Burundi, the failure and ethnic politicization of key government institutions resulted in a divorce between state institutions and the population. ${ }^{89}$ This meant that, although claiming to be a democratic regime, institutions no longer represented the needs of the people, nor did they function in order to provide sustainable livelihoods, protection against discrimination, economic opportunities, and positive relations between citizens. ${ }^{90}$ In contrast, the ethnicization of political and government institutions fueled dissatisfaction, mistrust, propaganda, and poverty among the Rwandan and Burundian populations. Without faith in the strength of government institutions, a democracy cannot function peacefully. Rwanda and Burundi are cases where this institutional failure led to violence and a lack of stability. ${ }^{91}$

Uvin $^{92}$ also discusses reliance on foreign and development aid as a factor that weakened institutions. Reliance on foreign and development aid reduced institutional capacity and ownership. It also negatively impacted the Rwandan and Burundian governments' political will and desire to meet citizens' needs and become self-reliant. Dependence on development aid created a cycle that demotivated both governments. They believed aid would replace institutional development and local capacity. Foreign aid essentially served as a crutch for institutions, weakening their actual ability and continuing to divorce them from the people. ${ }^{93}$

In addition, the desire to reach development goals was another factor that affected the strength of institutions. In the 1980s and 1990s, as donor countries emerged from the Cold War period, development aid became contingent on building democratic governments in East Africa. As many institutions were already corrupt and based on ethnic proof of power, democratization was neither a feasible or desirable option. Therefore, institutions attempted to develop according to democratic standards, which included democratic elections and the de-ethnicization of government. In reality however, the institutions were never truly democratized. ${ }^{94}$

Ndikumana writes specifically about institutional failure in Burundi, which was similar to Rwanda. He says:

Because key institutions such as the military, the judiciary, and the education system are controlled by ethnic and regional entities, the population feels alienated and disappointed by the inability of the state to protect its rights and advance its interests. The ruling elite has basically 'privatized' the state: through clientism, patronage, and rent seeking, state institutions are used to accumulate wealth and to serve and protect the interests of individuals and ethnic and regional entities. Violence is created and maintained in a vicious cycle of frustration-claims and counterclaims-and repression as the rulers try to hold onto power while the oppressed categories of the population claim for their fair share in national resources. ${ }^{95}$

The failure of institutions resulted in the deterioration of the economy in both Rwanda and Burundi, as they failed to build confidence and opportunity for citizens, and they were unable to reduce risk, distribute wealth, and create job opportunities. ${ }^{96}$ According to international relations

\footnotetext{
88 "Burundi: Bye-bye Arusha?" International Crisis Group, October 25, 2012.

${ }^{89}$ Ndikumana, Institutional Failure, 29-47.

${ }^{90}$ Ibid.

${ }^{91}$ Francis Fukuyama, “Social Capital, Civil Society, and Development," Third World Quarterly, 22, no.1 (2001), 7-20.

${ }_{92}$ Peter Uvin, “Prejudice, crisis, and genocide in Rwanda." African Studies Review 40, no. 02 (1997), 91-115.

${ }^{93} \mathrm{Ibid}$.

${ }^{94}$ Ibid.

${ }^{95}$ Ndikumana, Institutional Failure, 29-47.

${ }^{96}$ Ibid.
} 
theory, the most fundamental role of institutions is to create and facilitate a system where social exchange can exist without difficulty, ensuring that groups become better off economically and livelihoods generally rather than worse. ${ }^{97}$ The second role is to provide stability within the governmental system and economic and physical security. In Burundi and Rwanda, the failure of the state was fueled by the privatization of goods and services, in addition to a system of patronage. Specifically, in Rwanda, President Habyiramana, favored Hutu elites from Musanze, his home region in the north, and manipulation began due to patronage occurring in his home region. In Rwanda, Hutu elites, specifically under the Habyiramana regime, targeted Tutsi civilians. There were quotas in universities, government jobs, and other sectors of society that limited Tutsi participation and leadership. Propaganda and hate radio from Radio-Télévision Libre des Milles Collines (RTLM) flourished under the Habyiramana regime. The RTLM linked the Tutsi living in the country to the threat of the Rwandan Patriotic Front and Army, who launched failed invasions into Rwanda from Uganda in 1990 and 1992. ${ }^{98}$ This clear discriminatory policy from the Habyiramana party shows how institutions helped create structural and physical violence against Tutsi citizens.

Discriminatory policies in Rwanda and Burundi were present in both governments throughout the independence period. However, in Rwanda, structural and political violence was mainly one-sided. There were some killings of Hutus, specifically by the RPA during their invasion, however, politically, ideologically, and institutionally, there was clear, planned discrimination and dehumanization of the Tutsi. In Burundi, the violence was more two-sided in nature, with conflict fueling conflict between both sides. In both cases, however, power was maintained using violence. This was due to the failure of institutions to provide fair and equal access to all citizens. This analysis shows how institutional failure and a lack of democracy fueled and created a situation where patronage politics based on ethnicity and regional ties prevailed over fair institutions, aimed at aiding civilians.

Another key issue is the failure of the peacemakers to see the threat of genocide as the central issue that underlies civil strife in both Burundi and Rwanda. The label ascribed to a violent episode matters for the degree of attention paid, political will, and the level of international and regional investment given to the country in the aftermath of violence. Threats of genocide are not the only way to gain international clout, Commissions of Inquiry, investigations, and documenting human rights violations can also raise awareness nd commitment to transitional peace. For example, Rene Lemarchand claims:

The 1972 genocide in Burundi, like the 1994 genocide in Rwanda, is indeed the cataclysmic event which lies at the root of the Hutu-Tutsi conflict. This is where the historical experience of Burundi (and Rwanda) differs markedly from that of most other war-torn societies in Africa. Dealing with 'post-conflict' situations is one thing; healing the wounds of genocide is a very different matter. ${ }^{99}$

In terms of healing in countries traumatized by violence including ethnic cleansing and genocide, it is important to recognize the difference between post-conflict and post-genocide peacebuilding.

Indeed, in Rwanda, the international community, INGOs, the Rwandan government, and civil society have treated the country's experience as genocide. They have been sensitive to survivors' needs as survivors of genocide, not only mass atrocities or conflict. However, in Burundi, the lack of coherence among whether the 1972 and 1993 massacres were genocide has created a different approach to peacebuilding. Rwanda has received much international attention, especially in terms of international aid, development, post-genocide education, memorialization, reconciliation, and peacebuilding programs. Burundi has not received such attention. Second, Rwanda has

\footnotetext{
${ }^{97}$ Bhavnani and Backer, Localized Ethnic Conflict and Genocide, 283-306.

${ }_{98}$ Prunier, Rwanda Crisis.

${ }^{99}$ Lemarchand, The Dynamics of Violence.
} 
experienced more political stability than Burundi, stemming from the RPF government. This has allowed survivors to feel secure living in Rwanda, for the most part. Third, Rwanda became an experimental ground for transitional justice mechanisms after the genocide, and these efforts have been subject to much research and monetary investment. Burundi has not experienced such a surge of justice efforts, and it remains underdeveloped and in conflict today, when compared to Rwanda. According to Lemarchand and Weissman:

Amazingly, the 1972 killings of Hutu by Tutsi-what Stephen Weissman calls 'the first clear genocide since the Holocaust ${ }^{\prime 100}$ have sunk into near oblivion. The most obvious explanation for this extra-ordinary case of historical amnesia is the conspiracy of silence which, to this day, surrounds the circumstances of the killings, their scale, and their impact on subsequent developments. ${ }^{101}$

\section{Conclusion}

The past and present conflicts in Rwanda and Burundi led to the formation of different Arusha Accords with the singular desire to foster peace. However, both accords encountered difficulties and failed to prevent mass atrocities including genocide and continued war. While Rwanda has remained relatively stable under the RPF controlled Rwandan Government, Burundi has continued to encounter violence. April 2017 has marked two years of preventable atrocities in Burundi. The resurgence of violence has captured the lives of hundreds of innocent individuals, creating a mass refugee problem, and threatening to further destabilize the Great Lakes region if no action is taken. On April 25, 2015, the ruling CNDD-FDD announced that Pierre Nkurunziza would run for a third term in the June 26, 2015 presidential election. The announcement sparked protests by those opposed to Nkurunziza and those who claimed a third term would violate the country's constitution established at Arusha in 2005. The constitution states that no President can be elected more than twice. In May 2015, Burundi's Constitutional Court ruled in favor of Mr. Nkurunziza, amid reports of judges being intimidated. Tens of thousands fled violence amid protests. In July 2015 Nkurunziza was reelected. The polls were disputed, with opposition leader Agathon Rwasa describing them as "a joke." 102

Since December 2015 hundreds of individuals have been killed, and reports indicate that murders occur on a daily basis. According to the UNHCR, over 402,158 refugees have escaped to neighboring Rwanda, Tanzania, and Uganda, as of April 20, 2017. ${ }^{103}$ Michael Boyce of The East African stated, "make no mistake: What keeps Burundi 'quiet' these days is not peace, but fear. Cases of arbitrary arrests, torture, and disappearances are now on the rise - both in Bujumbura and in rural areas." 104

Just as Arusha in Rwanda did not prevent the 1994 genocide against the Tutsis, Arusha in Burundi has been reduced to a rhetorical and idealistic process that does not reflect the reality on the ground today in Burundi. The ruling party controls institutions and has blocked all options for power sharing, as stipulated in the ideals and conclusions of Arusha. Respect for rule of law and human rights has completely broken down, with a resurgence of openly ethnic rhetoric and propaganda encouraging youth militias to kill their neighbors to incite violence, which will help the ruling party maintain political control. The question remains, at what cost?

\footnotetext{
${ }^{100}$ Stephen R. Weissman, “Preventing Genocide in Burundi Lessons from International Diplomacy” (Washington, D.C.: United States Institute for Peace, 1998).

${ }^{101}$ Ibid.

${ }^{102}$ British Broadcast Corporation. "Burundi's Opposition Leader Rwasa Becomes Deputy Speaker," BBC News, July 30 , 2015, accessed October 26, 2018, https://www.bbc.com/news/world-africa-33722209.

103 “Refugee Situations," UNHCR, accessed April 21, 2017, https://data2.unhcr.org/en/situations/burundi.

${ }^{104}$ Michael Boyce, “UN police presence in Burundi can make dialogue more attractive, violence more costly," The East African, May 7, 2016.
} 


\section{Bibliography}

Beloff, Jonathan. "Lies we encounter when facing genocide denial." Times of Israel (blog), October 2, 2014. Accessed November 3, 2016. http://blogs.timesofisrael.com/hitlers-jewishbackground-and- other-lies/.

Beswick, Danielle. "Peacekeeping, Regime Security and 'African Solutions to African

Problems': Exploring motivations for Rwanda's involvement in Darfur." Third World Quarterly 31, no. 5 (2010), 739-754. DOI: 10.1080/01436597.2010.503566

- "The Risks of African Military Capacity Building: Lessons from Rwanda." African Affairs 113, no. 451 (2014), 212-231. DOI: 10.1093/afraf/adu003

Bhavnani, Ravi and David Backer. "Localized Ethnic Conflict and Genocide Accounting for Differences in Rwanda and Burundi." Journal of Conflict Resolution 44, no. 3 (2000), 283-306. DOI: $10.1177 / 0022002700044003001$

Boyce, Michael. "UN police presence in Burundi can make dialogue more attractive, violence more costly." The East African, May 7, 2016. Accessed October 26, 2018. https://www. theeastafrican.co.ke/OpEd/comment/-/434750/3194280/-/s5uxa3/-/index.html.

British Broadcast Corporation. "Burundi's Opposition Leader Rwasa Becomes Deputy Speaker," BBC News, July 30, 2015. Accessed October 26, 2018. https://www.bbc.com/news/worldafrica-33722209.

Clark, Phil. "Must Academics Researching Authoritarian Regimes self-censor." Times Higher Education, November 28, 2013. Accessed November 1, 2016. https://www. timeshighereducation.co.uk/features/must-academics-researching-authoritarian-regimesself-censor/2009275.fullarticle.

Corbin, Jane. "Rwanda's untold story" BBC Two [Television series episode]. October 1, 2014. Accessed November 3, 2016. http://www.bbc.co.uk/programmes/b04kk03t.

Crisafulli, Patricia and Andrea Redmond. Rwanda, Inc.: How a devastated nation became an economic model for the developing world. New York: Palgrave Macmillan, 2012. DOI: $10.1017 / \mathrm{s} 0022278 \times 13000311$

Dallaire, Romeo. Shake Hands with the Devil: The Failure of Humanity in Rwanda. New York: Da Capo Press, 2003. DOI: 10.3138/cjh.40.2.390

Ensign, Margee M. and William Bertrand. Rwanda: History and Hope. New York: University Press of America, Inc, 2010.

Fisher, Jonathan. "Managing donor perceptions: Contextualizing Uganda's 2007 intervention in Somalia." African Affairs 111, no. 444 (2012), 404-423. DOI: 10.1093/afraf/ads023

"Structure, agency and Africa in the international system: Donor diplomacy and regional security policy in East Africa since the 1990s." Conflict, Security \& Development 13, no. 5 (2013), 537-567. DOI: 14678802.2013.849471

Fujii, Lee Ann. Killing Neighbors: Webs of Violence in Rwanda. Ithaca: Cornell University Press, 2009. DOI: 10.1017/s1537592709991095

Fukuyama, Francis. "Social Capital, Civil Society, and Development." Third World Quarterly 22, no.1 (2001), 7-20.

Gribbin, Robert. In the aftermath of genocide: The US role in Rwanda. Lincoln: iUniverse, 2005.

Guichaoua, Andre. From war to genocide: Criminal politics in Rwanda, 1990-1994. Madison: The University of Wisconsin Press, 2015.

International Crisis Group, "Burundi: Bye-bye Arusha?" Report 192, October 25 2012. Accessed October 26, 2018. https://www.crisisgroup.org/africa/central-africa/burundi/burundi-byebye-arusha.

International Crisis Group. "Insights from the Burundian Crisis (III), Back to Arusha and the Politics of Dialogue." July 7 2016. Accessed October 26, 2018. https://www.crisisgroup.org/africa/ central-africa/burundi/insights-burundian-crisis-iii-back-arusha-and-politics-dialogue.

Jackson, Robert and George Sorensen. Introduction to international relations: Theories and approaches, 2nd ed. Oxford: Oxford University Press, 2003.

Jefremovas, Villia. "Treacherous Waters: The Politics of History and the Politics of Genocide in Rwanda and Burundi." Africa 70, no. 2 (2000), 298-308.

DOI: $10.3366 /$ afr.2000.70.2.298 
Jessee, Erin, "Conducting Field Work." Canadian Journal of Development Studies/Revue Canadienne D'études Du Développement Publication Details 33, no. 2 (2012), 266-274.

DOI: $10.1080 / 02255189.2012 .687356$

Kimonyo, Jean-Paul.Rwanda's popular genocide: A perfect storm. London, Lynne Rienner Publishers, 2016.

Kinzer, Stephen. A Thousand Hills, Rwanda's Rebirth and the Man Who Dreamed It. Hoboken: John Wiley \& Sons, Inc., 2008. DOI: 10.1353/arw.0.0169

Krasner, Stephan. International regimes. Ithaca: Cornell University Press, 1983.

Lemarchand, Rene. The Dynamics of Violence in Central Africa. Philadelphia: University of Pennsylvania Press, 2009.

Mandani, Mahmood. When Victims Become Killers: Colonialism, Nativism, and the Genocide in Rwanda. Princeton, Princeton University Press, 2001.

Melvern, Linda. A People Betrayed, the Role for the West in Rwanda's Genocide. London: Zed Books, 2000.

Morgenthau, Hans, J. "Another Great Debate: The National Interest of the United States." American Political Science Review 46 (1954), 961-988. DOI: 10.2307/1952108

Nantulya, Paul.“Why the Arusha Accords Are Central,” Spotlight, Africa Center for Strategic Studies, 2015. Accessed October 26, 2018. https://africacenter.org/spotlight/burundi-whythe-arusha-accords-are-central/.

Ndikumana, Léonce. "Institutional failure and ethnic conflicts in Burundi." African Studies Review 41, no. 1 (1998), 29-47. DOI: 10.2307/524680

Newbury, Catherine and Newbury, David. "The Crisis in Rwanda." African Studies Association 27, no. 3 (1994), 9-11.

Pottier, Johan. Re-imagining Rwanda: Conflict, survival and disinformation in the late twentieth century. Cambridge, UK: Cambridge University Press, 2002.

Prunier, Gerard. The Rwanda Crisis: History of a Genocide. New York: Columbia University Press, 1997.

--------. Africa's World War Congo, The Rwandan Genocide, and the Making of a Continental Catastrophe. New York: Oxford University Press, 2009.

“Refugee Situations." UNHCR. Accessed April 21, 2017.

https://data2.unhcr.org/en/situations/burundi.

Reyntjens, Filip. "Rwanda ten years on: From genocide to dictatorship." African Affairs 103, no. 411 (2004), 177-210. DOI: 10.1093/afraf/adh045

---------. Political Governance in Post-Genocide Rwanda. New York: Cambridge University Press, 2013.

Rusagara, Frank. "The spread of the 'genocide ideology' within the great lakes region:

Challenges for Rwanda." In Rwanda Fast Forward: Social, Economic, Military, and Reconciliation Prospects, edited by Maddalena Campioni and Patrick Noack, 213-227. New York: Palgrave Macmillan, 2012.

Slim, Hugo. Review of On Complicity and Compromise by Chiara Lepora and Robert E. Goodin. Ethics \& International Affairs 27, no. 4 (2013). DOI: 10.1017/s0892679413000427

Straus, Scott and Lars Waldorf, eds. Remaking Rwanda: State Building and Human Rights After Mass Violence. Madison: University of Wisconsin Press, 2011. DOI: 10.3917/afco.240.0167

The Permanent Mission of Rwanda to the United Nations. "UN peacekeeping." 2014. Accessed November 3, 2016. http://rwandaun.org/site/un-peacekeeping.

Uvin, Peter. Aiding violence: the development enterprise in Rwanda. West Hartford: Kumarian Press, Inc, 1998.

. "Ethnicity and Power in Burundi and Rwanda: Different Paths to Mass Violence." Comparative Politics (1999), 253-271. DOI: 10.2307/422339

. "Prejudice, Crisis, and Genocide in Rwanda." African Studies Review 40, no. 2 (1997), 91115.

Waugh, Colin. Paul Kagame and Rwanda: Power, Genocide, and the Rwandan Patriotic Front. Jefferson: McFarland \& Company, Inc., 2004.

Weissman, Stephen R. Preventing Genocide in Burundi Lessons from International Diplomacy. Washington, D.C.: United States Institute for Peace, 1998. 
Zorbas, Eugene. "Aid dependence and policy independence: Explaining the Rwandan paradox." In Remaking Rwanda: State Building and Human Rights after Mass Violence, edited by Scott Straus and Lars Waldorf, 103-117. Madison: The University of Wisconsin Press, 2011. DOI: 10.3917/afco.240.0167 